\title{
Developing Students' Writing through Scaffolding Techniques in a Workshop Forum
}

\author{
Gihan Sidky \\ College of Graduate Studies in Education, Cairo University, Cairo, Egypt
}

\begin{abstract}
This study aimed at enhancing students' essay writing skills at the secondary stage through scaffolding techniques in a workshop forum. The participants of the study were 40 students at the first secondary stage in a governmental language school. Qualitative methods were used in data analysis; a sample of students' writings was analyzed in light of the academic writing assessment criteria (Rose et al. 2008). A pre-posttest was administered to highlight progress in students' writing in the three genres. Scaffolding techniques proved to be effective in improving students' writing skills, specifically in the selected writing genres the study focused on which was evident in their second and third drafts. Interviews with high school teachers of English emphasized students need for innovative scaffolding techniques to help them develop as efficient writers. The workshop forum encouraged students to work together as one team and to express their ideas fluently to excel in their writing assignments. Having an authentic reason for writing motivated them to do research and to refine their writing to be good enough to share with others.
\end{abstract}

Index Terms—scaffolding techniques, writing skills, writing genres, writing workshops

\section{INTRODUCTION}

Writing has always been a major obstacle facing students who study languages in general and English as a foreign language in specific. Students are required to express their ideas and feelings in a language that they have not mastered. Hence, they have struggled to find ways to achieve fluency in writing and teachers have always dug deep to find innovative teaching techniques to help students become better writers. Students frustration when getting their written work back full of red marks that provided no guidance for them to improve their written pieces needed to be addressed. Researchers worked on finding solutions and teachers are always faced with that challenge; how they could help students improve their writing.

In the context of teaching English as a foreign language (EFL), students who are in the first secondary stage are considered in the intermediate level (B2) according to the European Framework of Reference for Languages (1996). Students at that level:

- "Can write an essay or report which develops an argument, giving reasons in support of or against a particular point of view and explaining the advantages and disadvantages of various options.

- Can synthesize information and arguments from a number of sources.

- Can write short, simple essays on topics of interest.

- Can summarize, report and give his/her opinion about accumulated factual information on familiar routine and non-routine matters within his/her field with some confidence." (The Common European Framework of Reference for Languages, 1996).

Regarding the writing skills, the actual level of the students in most governmental schools is below the defined level for that stage. This assumption was supported by previous research on students at the secondary stage and by the results of analysis of a sample of students' writing. Students find difficulty when they are asked to write about a specific topic especially when they are given no assistance. This could be due to a number of factors among which are: the lack of a consistent method for teaching writing, students are memorizing paragraphs by heart, then recalling them when asked to rewrite about it on the exam. Interviewing teachers also ensured this lack of consistency in teaching writing, which resulted in deterioration in students' writing skills and loss of direction.

Through conducting the pilot study, analyzing students' writing samples and having interviews with English teachers, the research problem surfaced as English teachers didn't follow a defined teaching technique in teaching writing. Most teachers assigned students with a certain topic and gave them a number of elements to talk about without providing them with enough assistance throughout the process of writing. That led some students to feel that writing is such a huge burden they don't have the skills to fulfil. Most teachers focused on the grammatical aspects of writing and did not know how to provide students with needed guidance to improve their written piece. For the above mentioned reasons and for the importance of writing as a core component in the first secondary stage curriculum, this study seeks to answer the following main question:

How can teachers improve students' writing skills?

The following sub questions are derived from the main question:

What are the English writing skills required for first secondary stage students? 
What are the English writing skills that the students have?

What is the suggested teaching model which is based on scaffolding that helps to develop students' writing skills in the three defined genres: email/letter, essay, and autobiography?

What is the effectiveness of the proposed model in enhancing students' writing skills?

\section{LITERATURE REVIEW}

Vygotsky's social theory advocates that learning takes place in a social community where more capable adults provide needed assistance. Scaffolding students in a level above the level they reached proved to be helpful as students work within their mastery level but a little higher, which challenges them to achieve, but does not frustrate them if it is too high, or bore them if it's too low. Studies verified that scaffolding helps students move to the next developmental stage.

\section{Zone of Proximal Development (ZPD):}

The social constructivist theory (1978) suggests that mental functions appear on the social plane first with more capable peers or adults. Scaffolding occurs in what Vygotsky calls the Zone of Proximal Development (ZPD). It is defined as the distance between what a person can do independently and with the assistance of an adult; the distance between one's current level of development and the developmental level he/she can reach with adult's help. With more practice, the experience is internalized and one is capable of fulfilling the required task on their own and in new contexts. Pearson \& Fielding (1991) suggested a model that involves the gradual transfer of responsibility from the teacher to the student. Rogoff (1990) points out that scaffolding facilitates students job as it divides the task for them, while it keeps it a whole for the teacher, which helps students handle it in an authentic way (Pearson, 1996).

According to the National Curriculum Framework for English as a Foreign Language: Secondary Stage (Grades 10 12) students are expected to:

"Write creatively, in a range of different forms and media, with imagination and commitment."

Based on the skills specified in the common European Framework of Reference for Languages and in light of the National Curriculum for English as a foreign language, three types of writing are selected for this study. Every type will take approximately three weeks. They are:

1. Essay for or against: Problem solving (provision of a problem, finding solutions) about environmental issues.

2. Writing a letter/email describing a house for sale (Advertisement) (2-3 weeks). Design an advertisement for a journal or a magazine (authentic purpose)

3. Biography (writing about famous people). Students select the topic (politics- art- personal) according to their interest. Then they work towards authentic reason; for example, creating their own magazine.

The scaffolding techniques used are:

Modelling, peer editing, instructor editing, final product (group revision) in a workshop forum.

\section{Scaffolding:}

Wood, Bruner, and Ross (1976) defined scaffolding as a "process that enables a child or novice to solve a problem, carry out a task or achieve a goal which would be beyond his unassisted efforts" (p. 90). Other definitions include, "supported situations in which children can extend current skills and knowledge to a higher level of competence" (Rogoff, 1990, p. 93), "what teachers say and do to enable children to complete complex mental tasks they could not complete without assistance" (Pearson \& Fielding, 1991, p. 842), others describe scaffolding as "a process whereby a teacher monitors students' learning carefully and steps in to provide assistance on an as- needed basis" (Wharton McDonald et al., 1998, p. 116), or "a temporary supportive structure that teachers create to assist a student or a group of students to accomplish a task that they couldn't complete alone" (Graves, Watts, \& Graves, 1994, p. 44). Graves \& Graves (2003) added that scaffolding can help students better complete a task with less stress or in less time, or to learn more fully than they would have otherwise, Pressley (2002) defines scaffolding as that which gives support to a building under construction until it is strong enough to stand on its own. The situation is similar when a more capable person gives support to a student until he/she is able to achieve an academic goal. The support is provided only when the child needs it and until the child catches on.

The term scaffolding was first related to the Zone of Proximal Development; then Bruner (1978) used it to describe the verbal assistance given by a mother to her child, which leads to the development of language learning. Scaffolding also refers to the assistance provided by a tutor to a less skilled tutee in problem solving (Hekamaki, 2005). Wood et al. (1976) underline that scaffolding does not stop at the completion of the required task, however it further leads to the development of task competence at a rate that outperforms his/her unassisted effort. Walqui (2006) divides scaffolding into three pedagogical steps: First, the provision of a support structure, second the undertaking of activities, and third, the assistance given through interaction.

Nguyen (2013) points out that the use of scaffolding does not only apply to an interaction between a novice and an expert, but it has extended to include peer collaboration (e.g. De Guerrero \& Villamil, 2000; Barnard, 2002) as well as class interactions between a teacher and students (Riazi \& Rezaii, 2011). Van Lier (2004) proposes six qualities for scaffolding: First, continuity, which means the repetition of action over time; second contextual support, that means the presence of a safe learning community where errors are perceived as part of the learning process; third intersubjectivity, which includes reciprocal involvement and support; fourth flow, which refers to a natural communication that flows 
among participants; fifth contingency, this means the kind of support depends on the reactions of learners; sixth, handover/takeover, the role of learners increases as they gain more confidence and skills. Lidz (1991) proposes a list of components for assisted learning, which are summarized in table 1.

Table 1

Lidz's components of assisted learning via scaffolding

1. Influence the learner's actions through interaction, engagement of attention, and goals.

2. Highlight important aspects, mark relevant differences, and elaborate detailed information.

3. Draw on the learner's past experiences and potential future ones.

4. Visualize the learner's work through his/her eyes.

5. Share experiences that may stimulate new ideas.

6. Manipulating the task to facilitate problem solving and induce strategic thinking.

7. Encourage the learner that he/she has done something good to boost self-esteem.

8. Challenge the learner within but not beyond his/her ZPD.

9. Remember that the learning experience is the learners not the experts to avoid competition.

10. Be familiar with the learner's behavior and respond to it appropriately.

11. Give the learner a sense of caring and enjoyment in the task.

12. Find areas of improvement and communicate them to the learner.

Note: This table is an overview of research done by Lidz, C. S. (1991). Practitioner's Guide to Dynamic Assessment. New York:

Guilford Press.

\section{Genre:}

Hyland \& Paltridge (2011) define "genre" as "a set of texts that have similar socially recognizable purpose, rhetorical and structural elements. The term is used to distinguish different text types" (Hyland, 2004; Lee, 2012). Genre analysis aims at identifying the language used by people in these types of texts.

Shum (2010) defines genre as types of texts that have common social or communal purposes. He identifies the characteristics of genre as: a staged, goal-oriented, purposeful, cultural activity that refers to language in use.

Genre is also defined as any written or spoken texts that have objectives and "social action mapped onto text- types" Martin, 1985, cited in Shum, 2010, p. 30). Shum (2010) also adds that the study of writing using a genre-based approach underlines the importance of context in understanding writing. Each genre has a different schematic structure to fulfil its social function. Gibbons (2002) highlights the major characteristics for genre as follows: Every genre has a purpose, a particular structure, certain linguistic features, and it is culture specific.

\section{Writing Workshop:}

A writing workshop differs from other approaches to writing in many ways. Students in a writing workshop choose the topics they should write about (Avery, 1993). Students make decisions about what to write, when to revise, edit and publish their work. Writing sessions go through three steps: the first is a mini-lesson during which the teacher or a more competent student models elements of good writing, the second component is workshop during which students write on topics of their choice, then discuss elements of their writing with the teacher in a writing conference, and the third component is sharing. During this part students share their writing piece with their writing partner, then the teacher chooses one or two students to share their writing with the rest of the class in the author's role (Calkins, 1994 and Graves, 1994). Discussions and conversations are an important part of the writing workshop (Avery, 1993)

The conversation that takes place in the writing conferences is completely different from the kinds of conversations that occur in many classrooms (Cazden, 1988). As teachers don't dominate class discussions and give students guidance and support as co-learners (Avery, 1993). The teacher assists the student's learning to be able to complete his/her new task, which is termed "scaffolding" (Bruner, 1986). Scaffolding, whether given by the teacher or students, allows students to improve their writing. During peer work, students give each other feedback on their writing. The process of listening to one another's writing with the aim of enhancing it helps students reread their writing for an imagined reader, which research proved makes the difference between a good and a poor writer (Flower \&Hayes, 1980; Sommers, 1980). Social interaction between the teacher and the students and the students among themselves is mandatory for scaffolding to take place, which is based on the theories of social constructivism and cognitive apprenticeship (Collins, Brown \& Newman, 1989).

\section{Peer Editing:}

Research has indicated that mere correction of students writing errors in a foreign language does not lead to enhancement in their writing skills. But when students receive feedback from an expert along with error correction, their ability to correct these mistakes in their subsequent writings improves (Semke, 1982, 1984; Lalande, 1982; Kepner, 1991; Reichelt, 1999, 2001 Paten, 2002; Byrd, 2003; Yang, 2006).

Barnard (2002) uses a workshop methodology in which learners are given training to become experts in peer editing. He claims that this methodology enhances their self-assessment skills and self-confidence to assess others' writings. The results of this study showed significant improvement in the learners' writing as a result of the use of workshop and peer feedback. He recommended these kinds of workshops as he believes they have a huge impact on students writing, and their self-image as writers. Moreover, successful peer- editors learn a number of writing techniques, and gain critical analysis skills that impact their writing skills (Tang \& Tithecott, 1999; Paten, 2002).

Both writing workshop projects and peer-editing share the collaborative nature, which studies indicated facilitates writing skills development more than lecturing or any other teacher directed strategies (Mangelsdorf \& Schlumberger, 
1992; Nelson \& Murphy, 1993; De Guerrero \& Villamil, 1994; Lockhart \& Ng, 1995; McGroarty \& Zhu, 1997). Using peer- feedback also creates a sense of commitment, which leads to a richer learning community (De Guerrero \& Villamil, 1994). During the feedback debriefing sessions, students usually use peer-advising, clarification and sometimes their first language to help in the revision (Villamil \& de Guerrero, 1996). These actions are considered scaffolding writing techniques, which are led by "a long-term sense of direction and continuity, a local plan of action, and a moment-to-moment interactional decision-making" (van Lier, 1996, p. 199).

Writing workshops also allow students to write for authentic audience, which previous studies referred to its importance in raising students interest in writing because they feel that their writing counts. They can imagine their readers, which is thought to influence their writing as they perceive it as a means of communication not an academic task that is used only for assessment (Graves, 1994; Calkins, 1994; Atwell, 1998; Dahl \& Farnan, 1998; Elbow, 2002 Black, 2008, 2009; Kelley, 2009).

Kelley (2009) and Black (2009) conducted a study on their college second language students who were enrolled in their writing classes. The students were asked to write children's short stories, which they were asked to read to grade school students. They found out that their students writing improved substantially and also their dedication to creative writing as they were writing for a real purpose and they had real audience that they wrote for.

\section{METHOD}

\section{A. Design of the Study}

The study uses a quasi-experimental approach using one experimental group. The suggested instructional model uses scaffolding techniques as its basis. The writing skills for first secondary school students were defined through analyzing their writings in the three genres specified in the curriculum description and compared to the writing skills determined by the Common European Framework of Reference for that stage to identify the skills they mastered and the ones they need to develop. The suggested model uses scaffolding techniques that assist students in their writing tasks in the three genres specified in the curriculum: email/letter, essay, and autobiography.

\section{B. Participants}

The study participants are 40 students; 10 girls and 30 boys in their first secondary stage in Mustafa Kamel governmental language school, Omrania Zone, Giza governorate. Their age ranges between 16 and 17 years old. The students are in the intermediate language level (B2) according to the Common European Framework of Reference. The students are observed during their English A level writing classes.

\section{Instruments}

1. A checklist of the writing skills required for first secondary stage school students as listed in the Common European Framework of Reference (CFR). The list was validated by jury members.

2. A pre-posttest to determine students writing skills before and after the implementation of the suggested instructional model. The test was given to jury members to assess its validity. The test was administered to another sample after two weeks and the reliability level has been acceptable at 0.86 on Cronbach's alpha. The test was divided to three sections, each focused on one genre. Students writings were analyzed to define the writing skills students have and those that they lack to be incorporated in the suggested model.

3. An Assessment criterion (an analytic scoring rubric for writing skills was used to assess participants' writings before and after the implementation of the suggested model to measure students' progress in the items tested by the rubric. Items assessed included: genre, register, discourse, grammar, and graphic features (refer to appendix 1 for definitions of terms used in the analytic scoring rubric (Rose et al 2008).

\section{The Suggested Instructional Model}

The instructional model suggested is based on the sociocultural theory, specifically on incorporating scaffolding techniques in a workshop forum and measuring its impact on their writing. Students were presented with a new genre every three weeks.

First, they were asked to write in the specified genre. They would be provided with an explanation of that genre and its main characteristics, the next step they would be presented with a model to familiarize them with how capable others write in that genre. They would be asked to write their own piece using the vocabulary and resources introduced to facilitate their task. The following step would be to self-correct their writing with the help of a given model and some set criteria. In a workshop forum the students and the teacher discuss suggestions for improvement. Students then were asked to peer correct each other's writings. The final step would be for the instructor to correct students' writing. The three drafts give the students three chances to get feedback on their writing and consequently to improve it. For example, they were first asked to write an email/ a letter on an advertisement for selling a house they own. After following the steps mentioned above, they end up having an improved piece of writing. After three weeks of working on that genre, students were assigned a new task, which involves working on a new genre, this time an autobiographical sketch of someone they admire or look up to. The same process would be repeated in a workshop forum, students' 
writings were discussed and the three drafts would be corrected first by the student him/herself, followed by a peer correction, and by the instructor.

The scaffolding the students get during the workshops take many forms; provision of eloquent relevant vocabulary, getting various forms of feedback through self, peers and the instructor, and discussions, which lead to the enhancement of their writings.

The third task was argumentative essay that involves problem solving genre; students were asked to write about an environmental problem of their choice. Students were presented with a number of environmental problems to choose from. As is the case with the other two types of writings, these issues were discussed and related vocabulary was introduced, the teacher undergoes a discussion of each problem, explores causes and suggested solutions with the students, provides some resources for students to further explore the environmental problem they choose to write about. Students write their first draft, the instructor provides criteria for correction for students to self-correct, peer correct, and finally the instructor corrects their third draft after having discussions with the student in a workshop forum. Scaffolding students' drafts and the provision of suggestions for improvement lead to the enhancement of students' writings gradually and steadily.

\section{Statistical Results}

Comparing the results of the pre and posttests for the three tasks with which participants were assigned showed noticeable improvements in favor of the posttest results. Pre and posttest results are represented in table 1.

TABLE I

T Test To Indicate The Difference Between Pre-Measurement And Post-Measurement In The Three Task Grades Of The EXPERIMENTAL GROUP

\begin{tabular}{|c|c|c|c|c|c|c|c|}
\hline Domain & Measures & $\mathrm{N}$ & Mean & $\begin{array}{c}\text { Standard } \\
\text { Deviation }\end{array}$ & t-value & Significance & Indication \\
\hline \multirow{2}{*}{ Task 1} & Pre & 40 & 14,08 & 3,67 & \multirow{2}{*}{12,235} & \multirow{2}{*}{0,000} & \multirow{2}{*}{ Significan } \\
\hline & Post & 40 & 21,05 & 4,21 & & & \\
\hline \multirow{2}{*}{ Task 2} & Pre & 40 & 14,38 & 3,34 & \multirow{2}{*}{11,160} & \multirow{2}{*}{0,000} & \multirow{2}{*}{ Significant } \\
\hline & Post & 40 & 21,15 & 3,91 & & & \\
\hline \multirow{2}{*}{ Task 3} & Pre & 40 & 14,80 & 3,09 & \multirow{2}{*}{15,798} & \multirow{2}{*}{0,000} & \multirow{2}{*}{ Significan } \\
\hline & Post & 40 & 21,98 & 3,13 & & & \\
\hline
\end{tabular}

Table (1) shows the following:

- The values of $(\mathrm{T})$ were statistically significant in each of the three tasks; the statistical significance of all the T-tests was 0.000 indicating that there are statistically significant differences between the mean of the pre and the postexperimental measurement of the experimental group in the three tasks. The increase manifested in students' posttests results could be explained in terms of the scaffolding provided to students.

Table 2 presents students' writings in the three drafts, each corrected three times once by the student, then by a peer and finally by the instructor in light of academic writing assessment criteria (Rose et al., 2008)

TABLE II

T TEST TO INDICATE THE DIFFERENCE BETWEen DRAFTS In THE WRITING GRADES Of StUdENTS In THE EXPERIMENTAL GROUP.

\begin{tabular}{|c|c|c|c|c|c|c|c|}
\hline Domain & Measures & $\mathrm{N}$ & Mean & $\begin{array}{c}\text { Standard } \\
\text { Deviation }\end{array}$ & t-value & Significance & Indication \\
\hline \multirow{2}{*}{$\begin{array}{l}\text { Writing (persuasive essay) } \\
\text { (advertisement) } \\
\text { Email/letter }\end{array}$} & Draft 1 & 40 & 45,40 & 9,67 & \multirow{2}{*}{13,40} & \multirow{2}{*}{0,000} & \multirow{2}{*}{ Significant } \\
\hline & Draft 2 & 40 & 53,42 & 9,07 & & & \\
\hline \multirow{3}{*}{$\begin{array}{l}\text { Writing } \\
\text { Argumentative } \\
\text { essay } \\
\text { (Problem } \\
\text { Solving) }\end{array}$} & Draft 1 & 40 & & & \multirow{3}{*}{16,55} & \multirow{3}{*}{0,000} & \multirow{3}{*}{ Significant } \\
\hline & & & 45,40 & 9,67 & & & \\
\hline & Draft 3 & 40 & 60,60 & 9,30 & & & \\
\hline \multirow[b]{2}{*}{ (Autobiography) } & Draft 2 & 40 & 53,42 & 9,07 & \multirow[b]{2}{*}{15,84} & \multirow[b]{2}{*}{0,000} & \multirow[b]{2}{*}{ Significant } \\
\hline & Draft 3 & 40 & 60,60 & 9,30 & & & \\
\hline
\end{tabular}

Table (2) shows the following:

- The values of $(\mathrm{T})$ were statistically significant in each of the three drafts; the statistical significance of all the T-tests was 0.000 indicating that there were statistically significant differences between the averages of the drafts of the experimental group members. In comparing the average scores of the students in the first and second drafts, the differences were in favor of the second. By comparing the average scores of the students in the first and third drafts, the differences were in favor of the third draft. The second and third differences were in favor of the third draft, which indicates the improvement of the performance of the students of the experimental group from the first to the third in favor of the third draft. The table also summarizes the scaffolding techniques provided to students, who kept working on their three drafts through self, peer and instructor's corrections and in light of the given criteria. 
The criteria used are divided into genre, register, discourse, grammar and graphic features (Rose et al., 2008, appendix 1). Genre focuses on the appropriateness of the writing task. It questions whether the writing task follows suitable stages. Register involves field, tenor, mode, and phases. First, field addresses whether the writer understands, explains and interprets the topic in a coherent way. Secondly, tenor examines the objectivity of assessment if the genre involves evaluation. Mode focuses on the appropriateness of the technical and abstract language used. Phases is related to the text organization and its sequence.

Discourse is composed of four components: lexis, conjunction, reference, and appraisal. Lexis evaluates the use and sequence of lexical relations. Conjunction is concerned with the logical relations between sentences and phrases. Reference focuses on whether who or what referred to in the text is clear. Appraisal examines whether the evaluation of ideas, arguments, people, things and texts are used sensibly.

Grammar involves the organization of sentences and if it presents information clearly. The last component in the criteria is graphic features: It underlies the clarity of the layout, the appropriateness of illustrations used, the accurateness of spelling and punctuation.

\section{RESUlTS AND DisCUSSION}

The results indicated that scaffolding students' writings led to noticeable improvement in their writing skills, especially in terms of genre, register, discourse, grammar, and graphic features, which are the main components of the assessment criteria used. Regarding genre, the participants' writings were enhanced as students were not following the appropriate stages: introduction, body and conclusion and were confusing some of these stages. After the implementation of the model, this aspect improved as students received explicit instruction regarding the logical stages, had extensive discussions about what each stage involves, and were given some models that demonstrated the accurate use of such stages, which led to increase in students' scores regarding genre.

Register is divided into four components: field, tenor, mode, and phases. As far as field is concerned, a large number of students' writings showed some improvement as their writings became more coherent, well organized and followed logical order. This could be explained in light of the continuous feedback students receive in many forms, which led to awareness of the importance of expressing their ideas in a connected form to make sense for the readers. Tenor also showed improvement as students learned the importance of presenting their ideas objectively through supporting their thoughts with valid arguments based on facts. The model emphasized the objectivity of students' written ideas. Mode has also been enhanced as students were directed to using the appropriate language that suits the topic of their writing and among the scaffolding they receive is the provision of relevant vocabulary that students could use in their writing. Also phases showed some enhancement as students' written work in the second and third drafts was more organized.

The use of discourse relations has improved clearly. Regarding lexis, students use of words has developed remarkably as activities used in the workshops focused on the use of suitable words and the provision of lists of possible lexical relations: synonyms, antonyms, etc. Students have been familiarized with the accurate use of lexical relations through various scaffolding techniques. Concerning the use of conjunction, its use is enhanced due to the continuous feedback they received in different forms. Reference use was clearer as students became more conscious of the importance of using reference correctly to clarify the meaning. Appraisal showed great improvement as the discussion that took place during the workshops emphasized the importance of supporting one's ideas and arguments with facts.

Students use of grammar was enhanced as their common errors were discussed in the workshops and students were provided by models that represented clear presentation of information and good organization of sentences, which helped students to imitate its use and with practice led to its improvement. Finally, the use of graphic features has improved to a good extent especially students spelling and punctuation as students were directed to find out about the correct spelling and were provided with reliable sources that explain rules for accurate use of punctuation marks, etc. Students second and third drafts showed better spelling and more accurate use of punctuation marks.

\section{INTERPRETATIONS}

The results indicated noticeable progress in students writing, which was manifested in increase in students' scores in all defined domains: Genre, register, discourse, grammar and graphic features. The difference was clear between students' pre and posttest results in favor of the posttests'. The results supported those reached by previous studies (Pearson, 1996; De Guerrero \& Villamil, 2000; Graves and Graves, 2003; Hekamaki, 2005; Riazi \& Rezaii, 2011; Nguyen, 2013), which prove that scaffolding students' writings leads to enhancement on all levels. These results were also manifested in students' three drafts, which showed improvement in each stage. The combination of scaffolding techniques used were varied and gave guidance to students in many forms, which provided them with continuous support and allowed them to self-correct their errors and also to receive feedback from their peers and the instructor. These results coincided with results of previous research that ensured the positive influence of peer editing (Avery, 1993; Tang \& Tithecott, 1999; Barnard, 2002) and writing workshops (Calkins, 1994 and Graves, 1994; Dahl \& Farnan, 1998; Atwell, 1998; Elbow, 2002; Black, 2008, 2009; Kelly, 2009) on enhancing students writing skills. Having various sources for support allowed students to get many chances to keep working on their drafts and to reach their maximum 
potential in writing. Besides, working towards an authentic purpose motivated them to work enthusiastically to reach the specified goal and to refine their piece to share among real audience.

\section{SUGGESTED RESEARCH}

It is recommended that students are not left out without assistance. More scaffolding techniques need to be uncovered to assist students in writing, reading, speaking and listening. The assistance of a more capable adult proved to be helpful at all levels and with all age groups. Researchers need to keep working on scaffolding to discover its impact on students' skills on the short and long run. It also needs to be explored more fully in other areas of language use and with other skills, such as teaching, leadership, mentorship and supervision.

\section{ApPendix A. ACADEMIC Writing Assessment Criteria (Rose et AL., 2008)}

\begin{tabular}{|c|c|}
\hline Genre & Is the genre appropriate for the writing task? Does it go through appropriate stages? \\
\hline Register & $\begin{array}{l}\text { - Field: Does the writer understand, interpret and/or explain the topic coherently? } \\
\text { - Tenor: Are evaluations appropriately objective if required by the genre? } \\
\text { - } \quad \text { Mode: Is there an appropriate use of technical and/or abstract language if required by the genre? } \\
\text { Phases: Is the text organised in an appropriate sequence of phases? }\end{array}$ \\
\hline Discourse & $\begin{array}{ll} & \text { Lexis: Is the field well-constructed by technical lexis and sequences of lexical relations? } \\
\text { - } & \text { Conjunction: Are logical relations coherently constructed between sentences and phases? } \\
\text { - } & \text { Reference: Is it clear who or what is being referred to at each step of the text? } \\
\text { - } & \text { Appraisal: Is appraisal used judiciously to evaluate ideas, arguments, people, things and texts? }\end{array}$ \\
\hline Grammar & - $\quad$ Are sentences organised to present information coherently? Are written grammatical conventions used appropriately? \\
\hline $\begin{array}{l}\text { Graphic } \\
\text { Features }\end{array}$ & $\begin{array}{l}\text { - Is the layout clear, including paragraphs and sections? Are illustrations used appropriately and clearly? Is spelling } \\
\text { accurate? Is punctuation used appropriately? }\end{array}$ \\
\hline
\end{tabular}

\section{APPENDIX B. CEFR COMMON REFERENCE LEVELS}

\begin{tabular}{|c|c|c|c|c|c|c|c|}
\hline \multirow{2}{*}{$\begin{array}{l}\text { U } \\
\text { N } \\
\text { D } \\
\text { E } \\
\text { R } \\
\text { S } \\
\text { T } \\
\text { A } \\
\text { N } \\
\text { D } \\
\text { I } \\
\text { N } \\
\text { G }\end{array}$} & Listening & $\begin{array}{l}\text { I can understand familiar } \\
\text { words and very basic phrases } \\
\text { concerning myself, my } \\
\text { family and immediate } \\
\text { concrete surroundings when } \\
\text { people speak slowly and } \\
\text { clearly. }\end{array}$ & $\begin{array}{l}\text { I can understand phrases and } \\
\text { the highest frequency } \\
\text { vocabulary related to areas of } \\
\text { most immediate personal } \\
\text { relevance (e.g, very basic } \\
\text { personal and family } \\
\text { information, thopping, local } \\
\text { area, employment). I can } \\
\text { catch the main point in short, } \\
\text { clear, simple messages and } \\
\text { announcements. }\end{array}$ & $\begin{array}{l}\text { I can understand the main } \\
\text { points of clear standard } \\
\text { speech on familiar matters } \\
\text { regularly yncountered in } \\
\text { work, school, leisure, etc. I } \\
\text { can understand the main } \\
\text { point of many radio or TV } \\
\text { programmes on current } \\
\text { affairs or topics of personal } \\
\text { or professional interest when } \\
\text { the delivery is relatively } \\
\text { slow and clear. }\end{array}$ & $\begin{array}{l}\text { I can understand extended } \\
\text { speech and lectures and } \\
\text { follow even complex lines of } \\
\text { argument provided the topic } \\
\text { is reasonably familiar. I can } \\
\text { understand most TV news } \\
\text { and current affairs } \\
\text { programmes. I can } \\
\text { understand the majority of } \\
\text { films in standard dialect. }\end{array}$ & $\begin{array}{l}\text { I can understand extended } \\
\text { speech even when it isnot } \\
\text { clearly structured and when } \\
\text { relationships are only } \\
\text { implied and not signalled } \\
\text { explicitly. I can understand } \\
\text { television programmes and } \\
\text { films without too much } \\
\text { effort. }\end{array}$ & $\begin{array}{l}\text { I have no difficulty in understanding any } \\
\text { kind of spoken language, whether live or } \\
\text { broadcast, even when delivered at fast native } \\
\text { speed, provided I have some time to get } \\
\text { familiar with the accent. }\end{array}$ \\
\hline & Reading & $\begin{array}{l}\text { I can understand familiar } \\
\text { names, words and very } \\
\text { simple sentences, for } \\
\text { example on notices and } \\
\text { posters or in catalogues. }\end{array}$ & $\begin{array}{l}\text { I can read very short, simple } \\
\text { texts. I can find specific, } \\
\text { predictable information in } \\
\text { simple everyday material } \\
\text { such as advertisements, } \\
\text { prospectuses, menus and } \\
\text { timetables and I can } \\
\text { understand short simple } \\
\text { personal letters. }\end{array}$ & $\begin{array}{l}\text { I can understand texts that } \\
\text { consist mainly of high } \\
\text { frequency everyday or job- } \\
\text { related language. I can } \\
\text { understand the description of } \\
\text { events, feelings and wishes } \\
\text { in personal letters. }\end{array}$ & $\begin{array}{l}\text { I can read articles and reports } \\
\text { concemed with } \\
\text { contemporary problems in } \\
\text { which the writers adopt } \\
\text { particular attitudes or } \\
\text { viewpoints. I can understand } \\
\text { contemporary literary prose. }\end{array}$ & $\begin{array}{l}\text { I can understand long and } \\
\text { complex factual and literary } \\
\text { texts, appreciating } \\
\text { distinctions of style. I can } \\
\text { understand specialised } \\
\text { articles and longer technical } \\
\text { instructions, even when they } \\
\text { do not relate to my field. }\end{array}$ & $\begin{array}{l}\text { I can read with ease virtually all forms of the } \\
\text { written language, including abstract, } \\
\text { structurally or linguistically complex texts } \\
\text { such as manuals, specialised articles and } \\
\text { literary works. }\end{array}$ \\
\hline \multirow{2}{*}{$\begin{array}{l}\text { S } \\
\text { P } \\
\text { E } \\
\text { A } \\
\text { K } \\
\text { I } \\
\text { N } \\
\text { G }\end{array}$} & $\begin{array}{l}\text { Spoken } \\
\text { Interaction }\end{array}$ & $\begin{array}{l}\text { I can interact in a simple way } \\
\text { provided the other person is } \\
\text { prepared to repeat or } \\
\text { rephrase things at a slower } \\
\text { rate of speech and help me } \\
\text { formulate what Im trying to } \\
\text { say. I can ask and answer } \\
\text { simple questions in areas of } \\
\text { immediate need or on very } \\
\text { familiar topics. }\end{array}$ & $\begin{array}{l}\text { I can communicate in simple } \\
\text { and routine tasks requiring a } \\
\text { simple and direct exchange } \\
\text { of information on familiar } \\
\text { topics and activities. I can } \\
\text { handle very short social } \\
\text { exchanges, even though I } \\
\text { can't usually understand } \\
\text { enough to keep the } \\
\text { conversation going myself. }\end{array}$ & \begin{tabular}{l|} 
I can deal with most \\
situations likely to arise \\
whilst travelling in an area \\
where the language is \\
spoken. I can enter \\
unprepared into conversation \\
on topics that are fariliar, of \\
personal interest or petinent \\
to everyday life (e.g, family, \\
hobbies, work, travel and \\
current events).
\end{tabular} & $\begin{array}{l}\text { I can interact with a degree } \\
\text { of fluency and spontaneity } \\
\text { that makes regular } \\
\text { interaction with native } \\
\text { speakers quite possible. I can } \\
\text { take an active part in } \\
\text { discussion in familiar } \\
\text { contexts, accounting for and } \\
\text { sustaining my views. }\end{array}$ & $\begin{array}{l}\text { I can express myself fluently } \\
\text { and spontaneously without } \\
\text { much obvious searching for } \\
\text { expressions. I can use } \\
\text { language flexibly and } \\
\text { effectively for social and } \\
\text { professional purposes. I can } \\
\text { formulate ideas and opinions } \\
\text { with precision and relate my } \\
\text { contribution skilfully to those } \\
\text { of other speakers. }\end{array}$ & $\begin{array}{l}\text { I can take part effortlessly in any } \\
\text { conversation or discussion and have a good } \\
\text { familiarity with idiomatic expressions and } \\
\text { colloquialisms. I can express myself fluently } \\
\text { and convey finer shades of meaning } \\
\text { precisely. fif I do have a problem I can } \\
\text { backtrack and restructure around the } \\
\text { difficulty so smoothly that other people are } \\
\text { hardly aware of it. }\end{array}$ \\
\hline & $\begin{array}{l}\text { Spoken } \\
\text { Production }\end{array}$ & $\begin{array}{l}\text { I can use simple phrases and } \\
\text { sentences to describe where I } \\
\text { live and people I know. }\end{array}$ & $\begin{array}{l}\text { I can use a series of phrases } \\
\text { and sentences to describe in } \\
\text { simple terms my family and } \\
\text { other people, living } \\
\text { conditions, my educational } \\
\text { background and my present } \\
\text { or most recent job. }\end{array}$ & \begin{tabular}{l|} 
I can connect phrases in a \\
simple way in order to \\
describe experiences and \\
events, my dreams, hopes \\
and ambitions. I can briefly \\
give reasons and \\
explanations for opinions and \\
plans. I can narrate a story or \\
relate the plot of a book or
\end{tabular} & $\begin{array}{l}\text { I can present clear, detailed } \\
\text { descriptions on a wide range } \\
\text { of subjects related to my } \\
\text { field of interest. I can explain } \\
\text { a viewpoint on a topical issue } \\
\text { giving the advantages and } \\
\text { disadvantages of various } \\
\text { options. }\end{array}$ & $\begin{array}{l}\text { I can present clear, detailed } \\
\text { descriptions of complex } \\
\text { subjects integrating sub- } \\
\text { themes, developing particular } \\
\text { points and rounding off with } \\
\text { an appropriate conclusion. }\end{array}$ & $\begin{array}{l}\text { I can present a clear, smoothly-flowing } \\
\text { description or argument in a syle } \\
\text { appropriate to the context and with an } \\
\text { effective logical structure which helps the } \\
\text { recipient to notice and remember significant } \\
\text { points. }\end{array}$ \\
\hline $\begin{array}{l}\text { W } \\
\text { R } \\
\text { I } \\
\text { T } \\
\text { I } \\
\text { N } \\
\text { G }\end{array}$ & Writing & $\begin{array}{l}\text { I can write a stort, simple } \\
\text { postcard, for example } \\
\text { sending holiday greetings. I } \\
\text { can fill in forms with } \\
\text { personal details, for example } \\
\text { entering my name, } \\
\text { nationality and address on a } \\
\text { hotel registration form. }\end{array}$ & $\begin{array}{l}\text { I can write short, simple } \\
\text { notes and messages. I can } \\
\text { write a very simple personal } \\
\text { letter, for example thanking } \\
\text { someone for something. }\end{array}$ & \begin{tabular}{l|} 
I can write simple connected \\
text on topics which are \\
familiar or of personal \\
interest. I can write exporonal \\
letters describing experiences \\
and impressions.
\end{tabular} & $\begin{array}{l}\text { I can write clear, detailed text } \\
\text { on a wide range of subjects } \\
\text { related to my interests. I can } \\
\text { write an essay or report, } \\
\text { passing on information or } \\
\text { giving reasons in support of } \\
\text { or against a particular point } \\
\text { of vieww I can write letters } \\
\text { highlighting the personal } \\
\text { significance of events and } \\
\text { experiences. }\end{array}$ & $\begin{array}{l}\text { I can express myself in clear, } \\
\text { well-structured text, } \\
\text { expressing points of view at } \\
\text { some length. I can write } \\
\text { about complex subjects in a } \\
\text { letter, an essay or a report, } \\
\text { underlining what I consider } \\
\text { to be the salient issues. I can } \\
\text { select a style appropriate to } \\
\text { the reader in mind. }\end{array}$ & $\begin{array}{l}\text { I can write clear, smoothly-flowing text in } \\
\text { an appropriate style. I can write complex } \\
\text { letters reports or articles which present a } \\
\text { case with an effective logical structure } \\
\text { which helps the recipient to notice and } \\
\text { remember significant points. I can write } \\
\text { summaries and reviews of professional or } \\
\text { literary works. }\end{array}$ \\
\hline
\end{tabular}

\section{REFERENCES}

[1] Atwell, N. (1998). In the middle: New understandings about writing, reading, and learning. Portsmouth, NH: Heinemann.

[2] Barnard, I. (2002). Whole-class workshops: The transformation of students into writers. Issues of Writing, 12.2, 124-143.

[3] Black, C. (2009). Engaging students: Best Practices in Active Learning. Madison, WI: Atwood Publishing. 
[4] Brooke, M. (2015). Implementing the scaffolding interaction cycle to enable first year undergraduate students to write effective summary-reflections. Malaysian Journal of ELT Research, 11.2, 17-34.

[5] Bruner, J. (1978). The role of dialogue in language acquisition. In S. Jarvella \& W. Levett (eds.), The child's conception of language. New York: Max Plank Institut for Psycholinguistik, 214- 256.

[6] Byrd, D. (2003). Practical tips for implementing peer editing tasks in the foreign language classroom. Foreign Language Annals, 36.3, 434-441.

[7] Calkins, L. (1994). The art of teaching writing. Portsmouth, NH: Heinemann.

[8] Clark, K. F. \& Graves, M. F. (2005). Scaffolding students' comprehension of text. The Reading Teacher 58.6, 570-580.

[9] Council of Europe. (2001). Common European framework of reference for languages: Learning, teaching, assessment. Cambridge, U.K: Press Syndicate of the University of Cambridge.

[10] Dahl, K., \& Farnan, N. (1998). Children's writing: Perspectives from research. Paper presented at The National Reading Conference of the International Reading Association, Chicago, IL.

[11] Elbow, P. (2002). The role of publication in the democratization of writing. In C. Weber (ed.), Publishing with students: A comprehensive guide. Portsmouth, NH: Heinemann, 1-8.

[12] Graves, M.F., \& Graves, B.B. (2003). Scaffolding reading experiences: Designs for student success. Norwood, MA: Christopher-Gordon.

[13] Graves, M.F., Watts, S., \& Graves, B.B. (1994). Essentials of classroom teaching: Elementary reading. Boston: Allyn \& Bacon.

[14] Guerrero, M. de, \& Villamil, O. (1994). Social-cognitive dimensions of interaction in L2 peer revision. The Modern Language Journal, 78, 484-496.

[15] Hekamäki, L. (2005). Scaffolded assistance provided by EFL teacher during whole class interaction. Unpublished Ph.D. thesis, University of Jyväskyalä, Jyväskyalä.

[16] Kelley, K. (2009). Practice what you preach: A teacher educator is reminded of important lessons. The Clearing House: A Journal of Educational Strategies, Issues and Ideas, 82.3, 145- 151.

[17] Kepner, C. (1991). An experiment in the relationship of types of written feedback to the development of second language writing skills. The Modern Language Journal, 75, 305-313.

[18] Lalande, J. (1982). Reducing composition errors: An experiment. The Modern Language Journal, 66, 140-149.

[19] Lidz, C. (1991). Practitioner's guide to dynamic assessment. New York: Guilford Press.

[20] Lockhart, C, \& Ng, P. (1995). Analyzing talk in ESL peer response groups: Stances, functions, and contents. Language Learning, 45, 605-655.

[21] Mangelsdorf, K., \& Schlumberger, A. (1992). ESL student response stances in a peer-review task. Journal of Second Language Writing, 1, 235-254.

[22] McGroarty, M., \& Zhu, W. (1997). Triangulation in classroom research: A study of peer revision. Language Learning, 47, 1-43

[23] Nelson, G., \& Murphy, J. (1993). Peer response groups: Do L2 writers use peer comments in revising their drafts? TESOL Quarterly, 27, 135-141.

[24] North, B. (1996). The development of a common framework scale of language proficiency. Ph.D. thesis, Thames Valley University. Reprinted 2000, New York, Peter Lang.

[25] Paton, F. (2002). Approaches to productive peer review. In D. R. Pantoja, V. Yena, L. Miller, S., \& E. Waggoner (eds.), Strategies for teaching first-year composition. Urbana: NCTE, 290-300.

[26] Pearson, P.D., \& Fielding, L. (1991). Comprehension instruction. In R. Barr, Ml. Kamil, P. Mosenthal, \& P.D. Pearson (eds.), Handbook of reading research. Mahwah, NJ: Erlbaum, 815-860.

[27] Pressley, M. (2002). Reading instruction that works: The case for balanced teaching (2nd ed.). New York: Guilford.

[28] Reichelt, M. (1999). Toward a more comprehensive view of L2 writing: Foreign language writing. Journal of Second Language Writing, 8, 181-204.

[29] Reichelt, M. (2001). A critical review of foreign language writing research on pedagogical approaches. The Modern Language Journal, 85(A), 578-598.

[30] Rogoff, B. (1990). Apprenticeship in thinking. New York: Oxford University Press.

[31] Rose, D., Rose, M., Farrington, S. \& Page, S. (2008). Scaffolding academic literacy with indigenous health sciences students: An evaluative study. Journal of English for Academic Purposes 7.3, 165-179.

[32] Schwieter, J. W. (2010). Developing second language writing through scaffolding in the ZPD: A magazine project for an authentic audience. Journal of College Teaching \& Learning (TLC), 7.10, 31- 45. https://doi.org/10.19030/tlc.v7i10.154.

[33] Semke, H. (1982). Correcting students' freewriting - Help or hindrance? Paper presented at the American Council on the Teaching of Foreign Languages, New York, NY.

[34] Semke, H. (1984). Effects of the red pen. Foreign Language Annals, 1.7, 195-202.

[35] Van Lier, L. (2004). The ecology and semiotic of language learning: A sociocultural perspective. NY: Kluwer Academic Publishers.

[36] Villamil, O., \& Guerrero, M. de. (1996). Peer revision in the L2 classroom: Social-cognitive activities, mediating strategies, and aspects of social behavior. Journal of Second Language Writing, 5, 51-75.

[37] Walqui, A. (2006). Scaffolding instruction for English language learners: A conceptual framework. The International Journal of Bilingual Education and Bilingualism. 9.2, 159-180.

[38] Wharton-McDonald, R., Pressley, M., \& Hampston, J.M. (1998). Literacy instruction in nine first-grade classrooms: Teacher characteristics and student achievement. Elementary School Journal, 99,101-128.

[39] Wood, D., Bruner, J.S., \& Ross, G. (1976). The role of tutoring in problem solving. Journal of Child Psychology and Psychiatry, 17, 89-100.

[40] Yang, Y. (2006). Feedback on college EFL students' compositions. US-China Foreign Language, 4.W, 93-96. 
Gihan A. Sidky, Cairo, Egypt, obtained her MA in TESOL from School of Education, University of London, London, England in 1992. She got her PhD in English Teacher Education and Curriculum Studies from School of Education, University of Massachusetts, Amherst, USA in 2002. Her major field of study is teaching English as a foreign language. She worked as a part-time Associate Professor in the Early Literacy Education Program, Graduate School of Education at the American University in Cairo. She works as a full time Associate Professor in the English Teaching Department, Teacher Education and Curriculum Development Program, College of Graduate Studies in Education, Cairo University, Cairo, Egypt.

Dr. Sidky is the author of several articles, including the Power game: power dynamics between the teacher and the Students in a graduate seminar and The Efficacy of a PD program on enhancing on-the job teaching skills, published by the Canadian Center of Science and Education in 2017, and Enhancing post graduates' research skills through an intervention program in light of EAP approach, published by the Egyptian Council for Curriculum and Instruction in 2018. 